\title{
PENDIDIKAN KaRAKTER SISWA melaluI pelajaran bahasa INDONEsIa
}

\author{
FATMA NURAINI PUTRI \\ Universitas Muhammadiyah Jakarta \\ fatmanurainip@gmail.com
}

Pertama Diterima: 27 Desember 2019

Bukti Akhir Diterima: 29 Juni 2020

\begin{abstract}
Abstrak
Penelitian ini dilatarbelakangi kurang berperan aktifnya pembelajaran Bahasa Indonesia dalam kehidupan sehari-hari. Para siswa pada umumnya belum memiliki daya apresiasi yang maksimal terhadap mata pelajaran Bahasa Indonesia. Keinginan untuk memahami mata pelajaran Bahasa Indonesia belum tumbuh dengan baik, sehingga hasil belajar yang diperoleh belum maksimal. Tujuan dari penelitian ini adalah untuk lebih memfokuskan mata Pelajaran Bahasa Indonesia sesuai dengan minat dan karakter siswa serta peran guru dalam upaya pembinaan dan pembelajaran Bahasa Indonesia. Guru memegang peranan sangat penting dan menjadi teladan dalam kemampuan berbahasa. Agar tujuan pembelajaran dapat terwujud, maka diperlukan pengetahuan dan pemahaman guru mengenai mata pelajaran Bahasa Indonesia. Metode yang digunakan dalam penelitian ini adalah metode penelitian deskriptif kualitatif. Berdasarkan hasil yang dapat diketahui bahwa Mata Pelajaran Bahasa Indonesia sangat berperan aktif terhadap kemampuan berbahasa dan menggambarkan karakter pribadi seseorang.
\end{abstract}

Kata Kunci: Pembelajaran Bahasa, Pembentukan Karakter

\section{Abstract}

This research is motivated by the lack of active role in learning Indonesian in daily life. Students in general do not have the maximum appreciation of Indonesian subjects. The desire to understand Indonesian subjects has not grown well, so the learning outcomes obtained have not been maximized. The purpose of this study is to focus more on Indonesian Language subjects in accordance with the interests and character of students and the role of the teacher in the efforts of fostering and learning Indonesian. The teacher plays a very important role and becomes a role model in language skills. So that learning objectives can be realized, the teacher's knowledge and understanding of Indonesian subjects is needed. The method used in this research is descriptive qualitative research method. Based on the results, it can be seen that Indonesian Language Subjects play an active role in language skills and describe a person's personal character.

Keywords: Language Learning, Character Building

\section{PENDAHULUAN}

Pendidikan adalah usaha sadar untuk menyiapkan peserta didik melalui kegiatan bimbingan, pengajaran dan atau latihan bagi peranannya di masa yang akan datang. Pada hakikatnya pembelajaran bahasa, khususnya bahasa Indonesia yaitu belajar berkomunikasi dalam upaya meningkatkan kemampuan siswa untuk berkomunikasi secara lisan dan tertulis serta untuk mengembangkan kemampuan menggunakan bahasa Indonesia dalam segala fungsinya yaitu sebagai sarana berpikir atau bernalar. Di lembaga pendidikan yang bersifat formal seperti sekolah, keberhasilan pendidikan dapat dilihat dari hasil belajar siswa dalam prestasi belajarnya. Kualitas dan keberhasilan belajar siswa sangat dipengaruhi oleh kemampuan dan ketepatan guru memilih dan menggunakan metode pengajaran.

Kenyataan di lapangan, khususnya dalam mata pelajaran bahasa Indonesia, kegiatan pembelajarannya masih dilakukan secara klasikal. Pembelajaran lebih ditekankan pada model yang 
banyak diwarnai dengan ceramah dan bersifat guru sentris. Hal ini mengakibatkan siswa kurang terlibat dalam kegiatan pembelajaran. Kegiatan siswa hanya duduk, diam, dengar, catat, dan hafal. Kegiatan ini mengakibatkan siswa kurang ikut berpartisipasi dalam kegiatan pembelajaran yang cenderung menjadikan mereka cepat bosan dan malas belajar.

Melihat kondisi demikian, maka perlu adanya alternatif pembelajaran yang berorientasi pada bagaimana siswa belajar menemukan sendiri informasi, menghubungkan topik yang sudah dipelajari dan yang akan dipelajari dalam kehidupan sehari-hari, serta dapat berinteraksi multi arah baik bersama guru maupun selama siswa dalam suasana yang menyenangkan dan bersahabat. Pembelajaran Bahasa Indonesia diarahkan untuk meningkatkan kemampuan siswa berkomunikasi dalam Bahasa Indonesia dengan baik dan benar, baik secara lisan maupun tulis, serta menumbuhkan apresiasi terhadap hasil karya kesastraan masyarakat Indonesia, Depdiknas (2006).

Bahasa memiliki peran sentral dalam perkembangan intelektual, sosial, dan emosional siswa dan merupakan penunjang keberhasilan dalam mempelajari semua bidang studi. Menyadari peran yang demikian, pembelajaran bahasa diharapkan dapat membantu siswa mengenal dirinya, budayanya dan budaya orang lain, mengemukakan gagasan dan perasaan, berpartisipasi dalam masyarakat yang menggunakan bahasa tersebut, dan menemukan serta menggunakan kemampuan analitis dan imaginatif yang ada dalam dirinya, Depdiknas (2006).

Menurut Keraf (1997) bahasa adalah alat komunikasi antara anggota masyarakat berupa simbol bunyi yang dihasilkan oleh alat ucap manusia. Menurut Felicia (2001), bahasa adalah alat yang digunakan untuk berkomunikasi sehari-hari, baik bahasa lisan atau pun bahasa tulis. Menurut Sunaryo (2000) bahasa di dalam struktur budaya ternyata memiliki kedudukan, fungsi serta peran ganda, bahasa sendiri adalah sebagai akar serta produk budaya yang sekaligus berfungsi sebagai sarana berfikir dan sarana pendukung pertumbuhan serta perkembangan ilmu pengetahuan dan teknologi.

Hal ini sesuai dengan UU No. 20 Tahun 2003 Tentang Sistem pendidikan nasional pada pasal 3, yang menyebutkan bahwa Pendidikan Nasional berfungsi mengembangkan kemampuan dan membentuk karakter serta peradaban bangsa yang bermartabat dalam rangka mencerdaskan kehidupan bangsa.

Pengertian Pendidikan karakter adalah hal positif apa saja yang dilakukan guru dan berpengaruh kepada karaktersiswa yang diajarnya. Pendidikan karakter adalah upaya sadar dan sungguhsungguh dari seorang guru untuk mengajarkan nilai-nilai kepada siswanya, Winton (2010).

Pendidikan karakter telah menjadi sebuah pergerakan Pendidikan yang mendukung pengembangan sosial, pengembangan emosional dan pengembangan etik para siswa. Merupakan suatu upaya proaktif yang dilakukan mengembangkan inti pokok dan nilai-nilai etik dan nilai-nilai kinerja, seperti kepedulian, kejujuran, kerajinan, fairness, keuletan dan ketabahan, tanggung jawab, menghargai diri sendiri dan orang lain.

Khon dalam Noll (2006) menyatakan bahwa pada hakikatnya "Pendidikan karakter dapat didefinisikan secara luas atau secara sempit. Dalam makna yang luas pendidikan karakter mencakup hampir seluruh upaya sekolah di luar bidang akademis terutama yang bertujuan untuk membantu siswa tumbuh menjadi seseorang yang memiliki karakter yang baik. Dalam makna yang sempit Pendidikan karakter dimaknai sebagai sejenis pelatihan moral yang merefleksikan nilai tertentu".

Jadi, pendidikan karakter adalah proses pemberian tuntunan kepada peserta didik untuk menjadi 
manusia seutuhnya yang berkarakter dalam dimensi hati, pikir, raga, serta rasa dan karsa. Pendidikan karakter dapat dimaknai sebagai pendidikan nilai, budi pekerti, pendidikan moral, pendidikan watak, yang bertujuan mengembangkan kemampuan peserta didik untuk memberikan keputusan baik-buruk, memelihara apa yang baik, dan mewujudkan kebaikan itu dalam kehidupan sehari-hari dengan sepenuh hati.

\section{METODE PENELITIAN}

Metode yang digunakan dalam penelitian ini adalah metode deskriptif kualitatif. Arikunto (2010) menerangkan "Penelitian Deskriptif merupakan penelitian yang dimaksudkan untuk mengumpulkan informasi mengenai status suatu gejala yang ada yaitu keadaan gejala menurut apa adanya pada saat penelitian dilakukan". Metode penelitian kualitatif merupakan metode pengkajian atau metode penelitian terhadap suatu masalah yang tidak dilaksanakan dengan menggunakan prosedur statistik tetapi deskriptif atau memaparkan, Khotari, et al. (2014).

Menurut Semi (2012) Metode deskriptif adalah metode yang dilakukan dengan tidak menggunakan angka-angka, tetapi menggunankan penghayatan terhadap interaksi antarkonsep yang sedang dikaji secara empiris.

\section{HASIL DAN PEMBAHASAN}

\section{Pendidikan Karakter}

\section{Nilai-nilai Karakter}

Draf Grand Design Pendidikan Karakter diungkapkan nilai-nilai yang terutama akan dikembangkan dalam budaya satuan pendidikan formal dan nonformal, dengan penjelasannya sebagai berikut.

- Jujur, menyatakan apa adanya, terbuka, konsisten antara apa yang dikatakan dan dilakukan (berintegritas), berani karena benar, dapat dipercaya (amanah, trustworthiness), dan tidak curang (no cheating).

- Tanggung jawab, melakukan tugas sepenuh hati, bekerja dengan etos kerja yang tinggi, berusaha keras untuk mencapai prestasi terbaik (giving the best), mampu mengontrol diri dan mengatasi stress, berdisiplin diri, akuntabel dengan pilihan dan keputusan yang diambil.

- Cerdas, berpikir secara cermat dan tepat, bertindak dengan penuh perhitungan, rasa ingin tahu yang tinggi, berkomunikasi efektif dan empatik, bergaul secara santun, menjunjung kebenaran dan kebajikan, mencintai Tuhan dan lingkungan.

- Sehat dan bersih, menghargai ketertiban, keteraturan, kedisiplinan, terampil, menjaga diri, dan lingkungan, menerapkan pola hidup seimbang.

- Peduli, memperlakukan orang lain dengan sopan, bertindak santun, toleran terhadap perbedaan, tidak suka menyakiti orang lain, mau berbagi, tidak merendahkan orang lain, tidak mengambil keuntungan dari orang lain, mau bekerja sama, mau terlibat dalam kegiatan masyarakat, menyayangi manusia dan mahluk lain, setia, cinta damai dalam menghadapi persoalan.

- Kreatif, mampu menyelesaikan masalah secara inovatif, luwes, kritis, berani mengambil keputusan dengan cepat dan tepat, menampilkan sesuatu secara luar biasa (unik), memiliki ide baru, ingin terus berubah, dapat membaca situasi dan memanfaatkan peluang baru.

Pusat Kurikulum Badan Penelitian dan Pengembangan Kementrian Pendidikan Nasional dalam publikasinya berjudul Pedoman Pelaksanaan Pendidikan Karakter (2011) menyatakan bahwa 
pendidikan karakter pada intinya bertujuan membentuk bangsa yang tangguh, kompetitif, berahlak mulia, bermoral, bertoleran, gotong royong, berjiwa patriotik, berkembang dinamis, berorientasi ilmu pengetahuan dan teknologi yang semuanya dijiwai oleh iman dan takwa kepada Tuhan Yang Maha Esa berdasarkan Pancassila.

Dalam Publikasi Pusat Kurikulum tersebut dinyatakan bahwa Pendidikan karakter berfungsi (1) mengembangkan potensi dasar agar berpotensi baik, dan berperilaku baik; (2) memperkuat dan membangun perilaku bangsa yang multikultur; (3) meningkatkan peradaban bangsa yang kompetitif dalam pergaulan dunia. Dalam kaitan itu telah diidentifikasi sejumlah nilai pembentuk karakter yang merupakan hasil kajian empirik Pusat Kurikulum. Nilai-nilai yang bersumber agama, Pancasila, budaya, dan tujuan Pendidikan Nasional tersebut adalah: (1) Religius; (2) Jujur; (3) Toleransi; (4) Disiplin; (5) Kerja keras; (6) Kreatif; (7) Mandiri; (8) Demokratis; (9) Rasa ingin tahu; (10) Semangat Kebangsaan (11) Cinta Tanah Air; (12) Menghargai Prestasi; (13) Bersahabat/Komunikatif; (14) Cinta Damai; (15) Gemar Membaca; (16) Peduli Lingkungan; (17) Peduli Sosial; dan (18) Tanggung Jawab.

\section{Strategi dan Metodologi Pendidikan Karakter}

Strategi dapat dimaknai dalam kaitannya dengan kurikulum, strategi dalam kaitannya dengan model tokoh, serta strategi dalam kaitannya dengan metedologi. Dalam kaitannya dengan kurikulum, strategis yang umum dilaksanakan adalah mengintegrasikan pendidikan karakter dalam bahan ajar. Artinya, tidak membuat kurikulum pendidikan karakter sendiri. Strategi terkait dengan adanya model tokoh yang sering dilakukan di negara-negara maju adalah bahwa seluruh tenaga kependidikan harus mampu menjadi model teladan yang baik.

Dalam kaitannya dengan metodologi, strategi yang umum diimplementasikan pada pelaksanaan pendidikan karakter di negara-negara barat (Wikipedia, 2011, dan Withlwy, 2007) antara lain adalah strategi pemanduan (cheerleading), pujian dan hadiah (praise-and-reawrd), definiskan dan latihkan (define-end-drill), penegakan disiplin (forced-formality), dan juga perangai bulan ini (traits of the month).

Sesuai dengan Desain Induk Pendidikan karakter dirancang Kementrian Pendidikan Nasional (2010) strategi pengembangan pendidikan karakter yang akan diterapkan di Indonesia antara lain melalui transformasi budaya sekolah (school culture) dan habituasi melalui kegiatan ekstrakulikuler. Jadi implementasi pendidikan karakter melalui transformasi budaya dan perikehidupan sekolah, dirasakan lebih efektif dari pada merubah kurikulum dengan menambahkan materi pendidikan karakter ke dalam muatan kurikulum.

Terkait metedelogi yang sesuai untuk Pendidikan karakter, Lickona (1991) menyarankan agar pendidikan karakter berlangsung efektif maka guru dapat mengusahakan implementasi berbagai metode seperti bercerita tentang berbagai kisah, cerita atau dongeng yang sesuai, menguasai siswa membaca literatur, melaksanakan studi kasus, bermain peran, diskusi, debat tentang moral, dan juga penerapan pembelajaran kooperatif. Pada prinsipnya guru dan seluruh warga sekolah tidak dapat mengelak dan berkewajiban untuk selalu mengajarkan nilai-nilai yang baik yang seharusnya dilakukan, serta nilai-nilai yang buruk yang seharusnya dicegah dan tidak dilakukan pada setiap program sekolah. Beberapa metode antara lain:

1. Metode Bercerita, Mendongeng (Telling Story)

Metode ini pada hakikatnya sama dengan metode ceramah, tetapi guru lebih leluasa 
berimprovisasi. Misalnya melalui perubahan mimik, gerak tubuh, mengubah intonasi suara seperti keadaan yang hendak dilukiskan dan sebagainya. Sebagai variasi boleh saja justru para siswa yang bercerita, secara bergantian.

2. Metode Diskusi dan Berbagai Variannya

Kata diskusi berasal dari Bahasa Latin discussio, discussum atau discussi yang maknanya memeriksa, memperbincangkan, mempercakapkan, pertukaran pikiran, atau membahas. Diskusi didefinisikan sebagai proses pertukaran pikiran antara dua orang atau lebih tentang suatu masalah untuk mencapai tujuan tertentu. Atau dapat juga didefinisikan diskusi adalah pertukaran pikiran antara dua orang atau lebih yang bertujuan memperoleh kesamaan pandang tentang suatu masalah yang dirasakan bersama.

3. Metode Simulasi (Bermain Peran/Role Playing dan Sosiodrama)

Simulasi artinya peniruan terhadap sesuatu, jadi bukan sesuatu yang terjadi sesungguhnya. Dengan demikian orang yang bermain drama atau memerankan sesuatu adalah orang yang sedang menirukan atau membuat simulasi tentang sesuatu. Dalam pembelajaran suatu simulasi dilakukan dengan tujuan agar peserta didik memperoleh keterampilan tertentu, baik yang bersifat profesional maupun yang berguna bagi kehidupan sehari-hari. Dapat pula simulasi ditunjukkan untuk memperoleh pemahaman tentang suatu konsep atau prinsip, serta bertujuan untuk memecah suatu masalah yang relevan dengan Pendidikan karakter.

4. Metode atau Model Pembelajaran Kooperatif

Berdasarkan pendapat sejumlah ahli, metode ini dianggap paling umum dan paling efektif bagi implementasi Pendidikan karakter. Scott B. Watson dari School of Education, Faculty Publications and Presentations Liberty University (1992) dalam makalahnya yang berjudul The Essential Elements of Cooperative Learning menyatakan bahwa pembelajaran kooperatif adalah lingkungan belajar kelas yang memungkinkan siswa bekerja sama untuk mengerjakan tugas-tugas akademiknya dalam suatu kelompok kecil yang heterogen.

\section{Pendidikan Karakter yang Efektif}

Tujuan Pendidikan Indonesia berfungsi untuk mengembangkan potensi anak, membangun karakter dan moral. Menurut Winata (2017) membangun karakter dapat di desain melalui model pembelajaran yang membebaskan anak dan demokrati, tujuan ini dapat diperoleh melalui Pendidikan formal, informal, dan nonformal.

Agar pelaksanaan Pendidikan karakter berjalan efektif Lickona, et al. (2010) telang mengembangkan 11 (sebelas) prinsip untuk Pendidikan karakter yang efektif (11 principles of effective character education). Schwartz (2008) menguraikan kesebelas prinsip tersebut dengan sedikit penjelasan sebagai dibawah ini.

1. Pendidikan karakter harus mempromosoikan nilai-nilai etnik inti (ethical core values) sebagai landasan bagi pembentukan karakter yang baik.

2. Karakter harus dipahami secara komprehensif termasuk dalam pemikiran, perasaan, dan perilaku.

3. Pendidikan karakter yang efektif memerlukan pendekatan yang sungguh-sungguh dan proaktif serta mempromosikan nilai-nilai inti pada semua fase kehidupan sekolah.

4. Sekolah harus jadi komunitas yang peduli.

5. Menyediakan peluang bagi para siswa untuk melakukan tindakan bermoral. 
6. Pendidikan karakter yang efektif harus dilengkapi dengan kurikulum akademis yang bermakna dan menantang, yang menghargai semua pembelajar dan membantu mereka untuk mencapai sukses.

7. Pendidikan karakter harus secara nyata berupaya mengembangkan motivasi pribadi siswa.

8. Seluruh staf sekolah harus menjadi komunitas belajar dan komunitas moral yang semuanya saling berbagi tanggung jawab bagi berlangsungnya pendidikan karakter, dan berupaya untuk mengembangkan nilai-nilai inti yang sama yang menjadi panduan pendidikan karakter bagi para siswa.

9. Impementasi pendidikan karakter membutuhkan kepemimipinan moral yang diperlukan bagi staf sekolah maupun para siswa.

10. Sekolah harus merekrut orangtua dan anggota masyarakat sebagai partner penuh dalam upaya pendidikan karakter.

11. Evaluasi terhadap pendidikan karakter harus juga menilai karakter sekolah, menilai fungsi staf sekolah sebagai pendidik karakter, sampai pada penilaian terhadap bagaimana cara para siswa memanifestasikan karakter yang baik.

\section{Pendidikan Karakter dan Pembelajaran Bahasa Indonesia \\ Hubungan Pendidikan Karakter dengan Pembelajaran Bahasa Indonesia}

Pendidikan karakter mulai didengungkan di era Mendikbud, Muhammad Nuh. Menurutnya pendidikan di Indonesia mulai melupakan pembentukan karakter siswa. Atas dasar pemikiran itulah pendidikan saat ini harus memuat pendidikan karakter. Menurut Mulyasa (2011), pendidikan karakter memiliki makna yang lebih tinggi dari pendidikan moral, karena pendidikan karakter tidak hanya berbicara benar-salah, tetapi bagaimana menanamkan kebiasaan (habit) tentang hal-hal yang baik dalam kehidupan, sehingga peserta didik memiliki kesadaran dan pemahaman yang tinggi serta kepedulian terhadap komitmen untuk menerapkan kebijakan dalam kehidupan sehari-hari. Kaitannya dengan bahasa, bahasa memiliki peranan yang sangat penting dalam kehidupan manusia karena bahasa bersifat manusiawi. Artinya, bahasa sebagai alat komunikasi verbal hanya dimiliki manusia, Chaer \& Agustin (2004).

Karakter yang diungkapkan dalam hal ini merujuk pada pedoman Kementrian Pendidikan Nasional mengenai delapan belas karakter yang menjadi petunjuk pendidikan karakter, diantaranya religius, jujur, disiplin, kerja keras, semangat kebangsaan, cinta tanah air, peduli lingkungan, peduli sosial, tanggung jawab, rasa igin tahu, gemar membaca, kreatif, mandiri, demokratis, cinta damai, menghargai prestasi, tileransi dan komunikatif.

Terkadang tidak jarang dari gaya bahasa, bagaimana cara penyampaiannnya, ekspresinya, dan keefektifan bahasa yang digunakan dalam berkomunikasi dapat diketahui tingkat kejujuran atau kebenaran ucapan seseorang. Penggunaan tutur bahasa seseorang dalam berkomunikasi dapat diketahui tingkat intelektualitas seseorang.

Pendidikan Karakter dalam Pembelajaran Bahasa Indonesia yang digunakannya pun sopan dan santun. Kesopanan seseorang juga dapat dilihat dari bahasa yang digunakannya dalam berkomunikasi dengan orang lain. Bahasa menurut Kamus Besar Bahasa Indonesia berarti sistem bunyi yang arbitrer yang digunakan oleh anggota suatu masyarakat untuk bekerja sama, berinteraksi, dan mengidentifikasikan diri. Menurut Plato, bahasa pada dasarnya adalah pernyataan pikiran seseorang dengan perantaraan onomata (nama benda atau sesuatu) dan rhemata (ucapan) 
yang merupakan cermin dari ide seseorang dalam arus udara lewat mulut. Berdasar penjelasan Palto tersebut, dapat diartikan bahwa bahasa adalah alat komunikasi antara anggota masyarakat berupa simbol bunyi yang dihasilkan oleh alat ucap manusia. Mungkin ada yang keberatan dengan mengatakan bahwa bahasa bukan satu-satunya alat untuk mengadakan komunikasi. Mereka menunjukkan bahwa dua orang atau pihak yang mengadakan komunikasi dengan mempergunakan cara-cara tertentu yang telah disepakati bersama. Bahasa memberikan kemungkinan yang jauh lebih luas dan kompleks daripada yang dapat diperoleh dengan mempergunakan media. Bahasa haruslah merupakan bunyi yang dihasilkan oleh alat ucap manusia. Bukannya sembarang bunyi. Dan bunyi itu sendiri haruslah merupakan simbol atau perlambangan. Terlepas dari itu semua, prinsip pembelajaran bahasa Indonesia secara umum ada delapan, antara lain 1) Pembelajaran bahasa Indonesia harus diarahkan untuk lebih banyak memberikan porsi kepada pelatihan berbahasa yang nyata; 2) Tata bahasa diajarkan hanya untuk memberikan kesalahan ujar siswa; 3) Keterampilan berbahasa nyata menjadi tujuan utama; 4) Membaca sebagai alat untuk belajar; 5) Menulis dan berbicara sebagai alat berekspresi dan menyampaikan gagasan; 6) Kelas menjadi tempat berlatih menulis, membaca, dan berbicara dalam bahasa Indonesia; 7) Penekanan pengajaran sastra pada membaca sebanyak-banyaknya sastra Indonesia; dan 8) Pengajaran kosakata diarahkan untuk menambah kosakata siswa.

Berdasarkan hal itu, nampak bahwa pembelajaran bahasa Indonesia adalah banyak berlatih di kelas dengan menggunakan bahasa yang sesuai dengan situasi, baik yang nyata "senyatanya" melalui diskusi maupun yang nyata "tidak senyatanya" melalui kegiatan bermain peran. Melalui diskusi dan bermain peran dalam pembelajaran bahasa Indonesia, siswa dapat melakukan olah rasa, olah batin, dan olah budi secara intens sehingga secara tidak langsung siswa memiliki perilaku dan kebiasaan positif melalui proses apresiasi dan berkreasi melalui karya sastra. Melalui karya sastra, siswa juga akan mendapatkan pengalaman baru dan unik yang belum tentu bisa mereka dapatkan dalam kehidupan nyata. Melalui karya sastra siswa bisa belajar dan bergaul secara langsung tentang berbagai karakter mulia, bahwa melalui pendidikan bahasa Indonesia kita dapat membentuk karakter bangsa.

\section{Kedudukan dan Fungsi Bahasa dalam Pendidikan Karakter}

Bahasa Indonesia merupakan alat komunikasi lingual bangsa Indonesia, baik secara lisan maupun tertulis. Melalui bahasa, kebudayaan suatu bangsa dapat dibentuk, dibina, dan dikembangkan, serta dapat diturunkan kepada generasi-generasi berikutnya. Komunikasi melalui bahasa ini memungkinkan tiap orang untuk menyesuaikan dirinya dengan lingkungan fisik dan lingkungan sosialnya. Memungkinkan juga tiap orang untuk mempelajari kebiasaan, adat istiadat, kebudayaan serta latar belakangnya masing-masing. Inilah yang disebut fungsi dasar suatu bahasa, yaitu sebagai alat komunikasi. Fungsi-fungsi bahasa ini akan lebih terinci dan tercermin melalui kedudukan bahasa itu sendiri. Sebagai bahasa nasional atau bahasa pemersatu, Bahasa Indonesia mempunyai fungsi sebagai: (1) lambang kebanggaan kebangsaan, (2) lambang identitas nasional, (3) alat perhubungan antardaerah, antarwilayah, dan antarwarga, (4) alat penyatuan berbagai suku bangsa. Sementara sebagai bahasa negara/resmi kenegaraan, bahasa Indonesia mempunyai fungsi sebagai: (1) bahasa resmi kenegaraan, (2) bahasa pengantar di dalam dunia pendidikan, (3) alat perhubungan pada tingkat nasional untuk kepentingan perencanaan dan pelaksanaan pembangunan, (4) alat pengembangan kebudayaan, ilmu pengetahuan, dan teknologi, Arifin \& Tasai (2008). 
Selain fungsi-fungsi di atas, Menurut Santoso (2007) bahasa Indonesia sebagai alat komunikasi juga memiliki fungsi: (1) penyampai informasi, (2) fungsi ekspresi, (3) fungsi adaptasi dan integrasi, (4) fungsi kontrol sosial.

Menurut Arief (2012) dalam kegiatan belajar mengajar, strategi sangat penting untuk memperlancar tujuan pembelajaran. Strategi pembelajaran yang ditetapkan oleh guru akan bergantung pada pendekatan pembelajaran yang digunakan; sedangkan bagaimana menjalankan strategi tersebut dapat ditetapkan berbagai metode pembelajaran.

Dalam Undang-Undang nomor 20 tahun 2003, pasal 30 dinyatakan bahwa pendidikan adalah upaya sadar dan terencana dalam proses pembimbingan dan pembelajaran bagi individu agar tumbuh berkembang menjadi manusia yang mandiri, bertanggung jawab, kreatif, berilmu sehat, dan berakhlak (berkarakter) mulia. Sistem Pendidikan Nasional (Sisdiknas) menegaskan bahwa pendidikan nasional berfungsi mengembangkan kemampuan dan membentuk watak serta peradaban bangsa yang bertujuan untuk berkembangnya potensi peserta didik agar menjadi manusia yang beriman dan bertakwa kepada Tuhan Yang Maha Esa, berakhlak mulia, sehat, berilmu, cakap, kreatif, mandiri, dan menjadi warga negara yang demokratis, serta bertanggung jawab, Suyadi (2013).

Program pendidikan yang tidak hanya berfungsi sebagai lembaga yang memberdayakan anak dalam pengertian kecerdasan dan keterampilan, melainkan program pendidikan juga menawarkan tentang pentingnya menjaga moralitas dan peningkatan kemampuan pertimbangan rasional dalam pengambilan keputusan.

Dalam Kamus Besar Bahasa Bahasa Indonesia (2004), pengertian pendidikan adalah proses pengubahan sikap dan tata laku seseorang atau kelompok orang dalam usaha mendewasakan manusia melalui upaya pengajaran dan pelatihan; proses, cara, perbuatan mendidik. Jadi, pendidikan nasional mengemban misi untuk membangun manusia sempurna (insan kamil).

\section{PENUTUP}

Pendidikan karakter merupakan satu hal yang sangat penting karena menjadi proses pemberian tuntunan kepada peserta didik untuk menjadi manusia seutuhnya yang berkarakter dalam dimensi hati, pikir, raga, serta rasa dan karsa. Melalui metedologi dan strategi pendidikan karakter yang dilakukan oleh pengajar guna menciptakan pendidikan karakter yang efektif.

Pengajaran bahasa Indonesia dan sastra masih dianggap kurang mampu oleh sebagian besar peserta didik baik secara lisan maupun secara tertulis dan menganggap bahwa pembelajaran Bahasa Indonesia secara membosankan.

Maka dari itu untuk pembelajaran Bahasa Indonesia agar berhasil harus digunakan sistem pembelajaran melalui pendekatan yang dilakukan oleh para guru atau para pengajar baik terhadap pembelajaran Bahasa Indonesia maupun pembelajaran sastra. 


\section{DAFTAR PUSTAKA}

Astute, Tri. 2015. "Peranan Pembelajaran Bahasa dalam Pembentukan Karakter Siswa". Prosiding Seminar Nasional Bulan Bahasa UNIB, 331-340.

Departemen Pendidikan dan Kebudayaan. 1990. Kamus Besar Bahasa Indonesia. Jakarta: Balai Pustaka.

Depdiknas. 2003. UU No. 20 tahun 2003, Sistem Pendidikan Nasional. www.depdiknas.go.id

Devianty, Rina. 2017. "Peran Bahasa Indonesia dan Bahasa Daerah dalam Pendidikan Karakter". Jurnal Pendidikan Ilmu Sosial dan Budaya, 1(2).

Dharma, Kesuma dkk. 2011. Pendidikan Karakter Kajian Teori dan Praktek di Sekolah. Bandung: PT Remaja Rosdakarya.

Made Pidarta. 1997. Landasan kependidikan: Stimulus Ilmu Pendidikan Bercorak Indonesia. Jakarta: PT Rineka Cipta.

Samani, M dan Hariyanto. 2017. Konsep dan Model Pendidikan Karakter. Bandung: PT Remaja Rosdakarya.

Winata, W. 2017. "Developing activities of children's learning through homeschooling" International Journal of Multidisciplinary Research and Development, 4(12), 28-31. 